\title{
Growth Hormone Secretagogue Binding Sites in Peripheral Human Tissues*
}

\author{
MAURO PAPOTTI, CORRADO GHÈ, PAOLA CASSONI, FILOMENA CATAPANO, \\ ROMANO DEGHENGHI, EZIO GHIGO, AND GIAMPIERO MUCCIOLI
}

\author{
Departments of Biomedical Sciences and Oncology (M.P., P.C.), Anatomy, Pharmacology and Forensic \\ Medicine (C.G., F.C., G.M.) and Internal Medicine (E.G.), University of Turin, Turin, 10125 Italy; and \\ Europeptides (R.D.), Argenteuil 95108, France
}

\begin{abstract}
The family of GH secretagogues (GHS) includes peptidyl (hexarelin) and nonpeptidyl (MK 0677) molecules possessing specific receptors in the brain, pituitary, and thyroid. GHS receptor subtypes have also been identified in the heart; and a gastric-derived peptide, named ghrelin, has recently been proposed as a natural ligand. Our aim was to investigate the presence of GHS receptors in a wide range of human tissues, by radioreceptor assay with [ $\left.{ }^{125} \mathrm{I}\right] \mathrm{Tyr}-\mathrm{Ala}$-hexarelin. GHS receptors were detected mainly in the myocardium, but they were also present (in order of decreasing binding activity) in adrenal, gonads, arteries, lung, liver, skeletal muscle, kidney, pituitary, thyroid, adipose tissue, veins, uterus, skin, and lymphnode. In contrast,
\end{abstract}

negligible binding was found in parathyroid, pancreas, placenta, mammary gland, prostate, salivary gland, stomach, colon, and spleen. Hexarelin, MK 0677, and human ghrelin completely displaced the radioligand from binding sites of endocrine tissues, but MK 0677 and ghrelin were less potent than hexarelin. In nonendocrine tissues, both MK 0677 and ghrelin were inactive in displacement of $\left[{ }^{125} \mathrm{I}\right] \mathrm{Tyr}-\mathrm{Ala}$ hexarelin, whereas hexarelin was as active as a displacing agent in endocrine tissues. This study provides the first detailed analysis of the tissue localization of GHS receptors and suggests that a still unknown receptor subtype, specific for peptidyl GHS, may exist in the heart and in other tissues. (J Clin Endocrinol Metab 85: 3803-3807, 2000)
H SECRETAGOGUES (GHS) are synthetic, peptidyl [GH-releasing peptides (GHRPs)], and nonpeptidyl molecules that possess strong, dose-dependent, and reproducible GH-releasing activity in vivo in several species and in man. They are active by the iv, sc, intranasal route and even after oral administration (1-3). Both peptidyl and nonpeptidyl compounds also possess significant PRL- and ACTH/cortisol-releasing effect $(4,5)$. The neuroendocrine activities of GHRPs are mediated by specific receptors, which have originally been identified in the pituitary and the hypothalamus in humans $(6)$, as well as in rats $(7,8)$, using radiolabeled peptidyl ([ $\left.{ }^{125} \mathrm{I}\right] \mathrm{Tyr}-\mathrm{Ala}$-hexarelin) or radiolabeled nonpeptidyl GHS ([ ${ }^{35}$ S]MK 0677).

A specific animal and human GHS receptor has recently been cloned (9). It is encoded by a rare messenger RNA (mRNA) with a predicted open reading frame of 366 amino acids with a transmembrane topology typified by the Gprotein-coupled receptor family. Receptor transcripts are expressed in the pituitary and the hypothalamus $(4,9)$, and their sequence shows partial homology with the neurotensin receptor and other orphan receptors, such as GPR38, GPR39, and FM-3 $(10,11)$.

Received March 27, 2000. Revision received June 23, 2000. Accepted June 30, 2000

Address correspondence and requests for reprints to: G. Muccioli, Ph.D., Division of Pharmacology, Department of Anatomy, Pharmacology and Forensic Medicine, University of Turin, Via P. Giuria 13, 10125 Turin, Italy. E-mail: muccioli@medfarm.unito.it.

* Supported in part by grants (ex-60\% to G.M. and E.G.) from the Italian Ministry of University and Research, Rome; by a grant from Consiglio Nazionale delle Ricerche (Grant 98.03040.CT04 to E.G.); by a grant from Europeptides; and by a grant from Fondazione SMEM (Turin, Italy).
The hypothalamus and the pituitary gland display the highest specific GHS binding in humans and in animals (6-9), though a high level of specific binding has also been found in other areas of the central nervous system, such as the cerebral (but not cerebellar) cortex, hippocampus, medulla oblongata, choroid plexuses, thalamus, striatum, and substantia nigra $(4,6)$. The existence of GHS receptors in the brain and pituitary gland probably accounts for the endocrine and central activities of GHS (1-3). Recent evidence indicates that the distribution of the GHS receptor is not restricted to central organs, and the expression of type I GHS receptor mRNA has been demonstrated in the human pancreas (12) and in neuroendocrine tumors (13, 14). Radioiodinated peptidyl GHS are also able to label specific binding sites in the rat and human heart (15-17). There is already evidence, both in animals and in humans $(16,18-23)$, that cardiac GHS receptors could mediate biological activities that are probably independent from the effect on GH secretion. Very recently, a gastric-derived peptide, named ghrelin, has been proposed as a natural ligand for GHS receptor (24). It has been shown that ghrelin has a stimulatory effect on GH secretion in the rat, but its capacity to selectively bind the GHS receptor subtype identified with radiolabeled peptidyl GHS has not yet been elucidated.

Based on the foregoing, the aims of the present study were: 1) to investigate the presence of GHS binding sites in a wide range of peripheral endocrine and nonendocrine human tissues, by radioreceptor assay with $\left[{ }^{125} \mathrm{I}\right] \mathrm{Tyr}-\mathrm{Ala}$-hexarelin; and 2) to evaluate the ability of different unlabeled GHS (including ghrelin) to compete with the radioligand for binding sites in different tissues. 


\section{Subjects and Methods}

\section{Chemicals}

Hexarelin (His-D-2Me-Trp-Ala-Trp-D-Phe-Lys- $\mathrm{NH}_{2}$ ), Tyr-Alahexarelin, human ghrelin [Gly-Ser-Ser-(O n-octanoyl)-Phe-Leu-SerPro-Glu-His-Gln-Arg-Val-Gln-Gln-Arg-Lys-Glu-Ser-Lys-Lys-Pro-ProAla-Lys-Leu-Gln-Pro-Arg- $\left.\mathrm{NH}_{2}\right]$, and MK 0677 (N-[1(R) \{[1,2-dihydro1-methanesulphonylspiro-(3H-indole-3, 4'-piperidin)-1'-yl]-2-(phenylmethoxy)-ethyl\}-2-amino-2-methylpropanamide methane sulphonate) were supplied by Europeptides (Argenteuil, France). Human GHRH (GHRH 1-44) and SRIF (SRIF 1-14) were purchased from Bachem A. G. Feinchemikalien, Bubendorf, Switzerland. $\left.{ }^{[25} \mathrm{I}\right] \mathrm{Tyr}$-Ala-hexarelin (SA $1800-2100 \mathrm{Ci} / \mathrm{mmol}$ ) was iodinated using a lactoperoxidase method and purified by reverse-phase high-performance liquid chromatography, as previously described (6).

\section{Tissue samples}

Various autoptic and surgical human tissue specimens were included in this study. They comprised a wide range of peripheral tissues, both from endocrine (adrenal gland, ovary, pancreas, parathyroid, pituitary gland, testis, and thyroid gland) and nonendocrine organs (adipose tissue, aortic endothelium, aortic smooth muscle, carotid, colon, coronary, kidney, liver, lung, lymphnode, mammary gland, myocardium, prostate, salivary gland, skeletal muscle, skin, spleen, stomach, uterus, and vena cava). All postmortem tissues were obtained at autopsy from 10 patients [ 5 males, ranging in age from $24-63 \mathrm{yr}$ (median age, $53 \mathrm{yr}$ ); and 5 females, ranging in age from 27-54 yr (median age $46 \mathrm{yr}$ )] who died of trauma or neoplasms and were submitted to autopsy for diagnostic purposes, in years 1998 to 1999, in the Department of Pathology, University of Turin. Tissue removal had been given ethical approval by our hospital committee. Five samples of placenta from at-term spontaneous deliveries and 2 fragments each of adipose tissue, adrenal gland, colon, liver, lung, kidney, lymphnode, mammary gland, ovary, pituitary, prostate, salivary gland, skeletal muscle, skin, spleen, stomach, testis, thyroid, and uterus were also collected from surgical specimens received in the above Department in the same period. Of each specimen, a small (less than $1 \mathrm{~cm}^{3}$ ) tissue fragment (adjacent to the one fixed in formalin and used for histopathology) was immediately frozen at $-30 \mathrm{C}$ and stored for 1-14 months until processed for membrane preparation and binding studies. Although care was taken to collect all tissues from apparently normal organs, the absence of major pathological abnormalities was also confirmed by microscopic examination of adjacent tissue blocks of each specimen.

\section{Binding studies}

GHS binding assay with tissue membranes was performed using $\left[{ }^{125} \mathrm{I}\right] \mathrm{Tyr}$-Ala-hexarelin as radioligand $(6,25)$. The membrane fractions were prepared from frozen pieces of tissue using the method previously described for brain and pituitary gland (6). The thawed tissues were homogenized in 5-10 vol sucrose $0.3 \mathrm{~mol} / \mathrm{L}$. The homogenate was first centrifuged at $500 \times g$ at $4 \mathrm{C}$ for $10 \mathrm{~min}$, and the supernatant was carefully decanted and subjected to a second centrifugation at 30,000 $\times$ $g$ for $30 \mathrm{~min}$. The resulting pellet was resuspended in ice-cold buffer (50 $\mathrm{mmol} / \mathrm{L}$ Tris, $2 \mathrm{mmol} / \mathrm{L}$ EGTA, $0.03 \%$ bacitracin, titrated with $\mathrm{HCl}$ to $\mathrm{pH}$ 7.3) and immediately used to determine protein content (26) and for binding studies.

In preliminary experiments, it was found that equilibrium binding conditions for the different tissues were similar to those found for binding to human hypothalamus and pituitary gland (6). For saturation binding studies, tissue membranes (corresponding to $100 \mu \mathrm{g}$ protein) were incubated in triplicate, at $0 \mathrm{C}$ for $60 \mathrm{~min}$, with increasing concentrations $(0.25-20 \mathrm{nmol} / \mathrm{L})$ of $\left.{ }^{125} \mathrm{I}\right] \mathrm{Tyr}-\mathrm{Ala}$-hexarelin in a final vol of 500 $\mu \mathrm{L}$ assay buffer $(50 \mathrm{mmol} / \mathrm{L}$ Tris, $2 \mathrm{mmol} / \mathrm{L}$ EGTA, $0.1 \%$ BSA, $0.03 \%$ bacitracin, titrated with $\mathrm{HCl}$ to $\mathrm{pH}$ 7.3). Parallel incubations, where 2.5 $\mu \mathrm{mol} / \mathrm{L}$ unlabeled Tyr-Ala-hexarelin was also present, were used to determine nonspecific binding, which was subtracted from total binding to yield specific binding values. The binding reaction was terminated by adding ice-cold assay buffer followed by filtration through Whatman GF/B filters (Merck Eurolab s.r.e., Milan, Italy). Filters were rinsed three times with assay buffer, and the radioactivity remaining bound to the filters was measured by a Packard gamma counter A5003 (Packard
Bioscience s.r.e., Milan, Italy). Specific binding was calculated as the difference between binding in the absence and in the presence of excess unlabeled Tyr-Ala-hexarelin and was expressed as $\mathrm{fmol} / \mathrm{mg}$ protein. Precautions were taken to minimize variations in the binding of $\left[{ }^{125} \mathrm{I}\right] \mathrm{Tyr}-\mathrm{Ala}-\mathrm{h}$ exarelin to tissue fractions. Thus, all binding studies related to one membrane preparation were carried out using the same batch of radiotracer. Saturation isotherms were transformed using the method of Scatchard (27), and the number of binding sites (maximal binding capacities) and the dissociation constant $\left(\mathrm{K}_{\mathrm{d}}\right)$ for each tissue preparation were calculated with the Prism 3 program (GraphPad Software, Inc., San Diego, CA). To establish binding site specificity, increasing concentrations of various competitors (hexarelin, human ghrelin, MK 0677, GHRH, and SRIF) were tested in displacement assays with $\left[{ }^{125} \mathrm{I}\right] \mathrm{Tyr}$-Ala-hexarelin, and the $\mathrm{IC}_{50}$ values were calculated by iterative nonlinear curve-fitting program.

\section{Statistical analysis}

Values are expressed as median and range unless otherwise noted. In saturation and competition binding experiments, they are expressed as mean \pm SEM. The number of subjects is indicated by $n$. Significant differences between groups were assessed by one-way ANOVA followed by the Mann-Whitney test or Duncan's multiple-range test, depending on the experiments. $P<0.05$ was chosen as the level of significance.

\section{Results}

\section{Binding of $\left[{ }^{125} I\right] T y r-A l a-h e x a r e l i n$ to membranes from} various human tissues

Wide variations of binding were observed among the tissues studied (Table 1). The highest $\left[{ }^{125} \mathrm{I}\right] \mathrm{T} y \mathrm{r}-\mathrm{Ala}$-hexarelin binding activity was observed in the myocardium of both

TABLE 1. Specific binding of $\left[{ }^{125} I\right]$ Tyr-Ala-hexarelin to membranes from various autoptic human tissues

\begin{tabular}{|c|c|c|}
\hline \multirow{2}{*}{ Tissue } & \multicolumn{2}{|c|}{$\begin{array}{l}\text { Specific binding of }\left[{ }^{125} I\right] \text { Tyr-Ala-hexarelin } \\
\text { (fmol/mg protein) }\end{array}$} \\
\hline & Male subjects & Female subjects \\
\hline Myocardium & $4302(3897-4856)$ & $3987(3712-4564)$ \\
\hline Adrenal gland & $2853(2656-3024)$ & $2786(2442-3223)$ \\
\hline Testis & $2561(2243-2856)$ & - \\
\hline Aortic smooth muscle & $2434(1862-2521)$ & $2217(2034-2543)$ \\
\hline Aortic endothelium & $2366(1897-2658)$ & $2187(1816-2488)$ \\
\hline Coronary & $2245(1925-2452)$ & $2108(1686-2356)$ \\
\hline Carotid & $2005(1824-2206)$ & $1989(1665-2221)$ \\
\hline Lung & $1896(1789-2114)$ & $1865(1765-2023)$ \\
\hline Ovary & - & $1865(1786-2012)$ \\
\hline Liver & $1602(1435-1634)$ & $1498(1421-1558)$ \\
\hline Skeletal muscle & $1523(1404-1725)$ & $1478(1345-1723)$ \\
\hline Kidney & $1427(1285-1610)$ & $1356(1229-1532)$ \\
\hline Pituitary gland & $1184(990-1345)$ & $1205(1002-1353)$ \\
\hline Thyroid gland & $912(689-1095)$ & $1002(879-1121)$ \\
\hline Adipose tissue & $487(376-654)$ & $323(233-612)$ \\
\hline Vena cava & $406(267-546)$ & $434(312-673)$ \\
\hline Uterus & - & $302(223-482)$ \\
\hline Skin & $282(200-432)$ & $289(211-512)$ \\
\hline Lymphnode & $210(134-423)$ & $212(108-376)$ \\
\hline Parathyroid gland & $<10(0-5)$ & $<10(0-7)$ \\
\hline Pancreas & $<10(2-7)$ & $<10(0-4)$ \\
\hline Placenta ${ }^{a}$ & - & $<10(3-6)$ \\
\hline Mammary gland & - & $<10(4-7)$ \\
\hline Prostate & $<10(0-8)$ & - \\
\hline Salivary gland & $<10(6-9)$ & $<10(0-8)$ \\
\hline Stomach ${ }^{\circ}$ & $<10(0-3)$ & $<10(0-3)$ \\
\hline Colon & $<10(0-5)$ & $<10(3-5)$ \\
\hline Spleen & $<10(6-7)$ & $<10(2-9)$ \\
\hline
\end{tabular}

${ }^{a}$ From at-term spontaneous deliveries. Values from five subjects are expressed as median (range). 
sexes and ranged from $3712-4856 \mathrm{fmol} / \mathrm{mg}$ protein. The specific binding in the myocardium represented $70-82 \%$ of the total radioactivity bound. Adrenal gland, testis, aortic smooth muscle, aortic endothelium, coronary, carotid, lung, and ovary possessed intermediate binding, with values ranging from 1665-3223 fmol/mg protein; liver, skeletal muscle, kidney, pituitary gland, and thyroid gland also showed significant binding, in the range of $689-1725 \mathrm{fmol} / \mathrm{mg}$ protein. Low binding, ranging from $108-673 \mathrm{fmol} / \mathrm{mg}$ protein, was detected in membranes from adipose tissue, vena cava, uterus, skin, and lymphnode. By contrast, negligible binding $(<10 \mathrm{fmol} / \mathrm{mg}$ protein) was seen in the remaining tissues (parathyroid gland, pancreas, placenta, mammary gland, prostate, salivary gland, stomach, colon, and spleen). Differences in the specific binding values were statistically significant when comparing the myocardium with the other tissues $(P<0.001$ in both sexes); likewise the values obtained in adrenal gland, testis, aortic smooth muscle, aortic endothelium, coronary, carotid, lung, and ovary differed significantly $(P<0.01$ in both sexes) from those of liver, skeletal muscle, and kidney; differences in the binding values were also statistically significant for liver, skeletal muscle, and kidney $v$ s pituitary gland and thyroid gland $(P<0.05$ in both sexes) and for pituitary gland and thyroid gland $v$ s. adipose tissue, vena cava, skin, uterus, and lymphnode $(P<0.001$ in both sexes). No sex differences in the Tyr-Ala-hexarelin binding to various organs were observed. Determinations performed with the same batch of radiolabeled Tyr-Ala-hexarelin, on membranes from surgical or autopsy specimens of the same tissues, yielded overlapping binding values.

Representative saturation isotherms and Scatchard plots of $\left.{ }^{125} \mathrm{I}\right] \mathrm{Tyr}$-Ala-hexarelin binding to membranes from those tissues (myocardium and adrenal gland) that displayed the highest specific binding activity are shown in Fig. 1. Experiments using increasing concentrations of radiotracer revealed evidence of saturable specific binding in the myocardium and adrenal gland (Fig. 1a). Scatchard analysis of these data (Fig. 1b) demonstrated the existence in both tissues of a single class of high-affinity sites with $K_{d}$ values not substantially different from one another, being $5.5 \pm 1.3 \mathrm{nmol} / \mathrm{L}$ for males $(n=5)$ and $5.4 \pm 1.6 \mathrm{nmol} / \mathrm{L}$ for females $(n=5)$ in the myocardium and $6.5 \pm 1.2 \mathrm{nmol} / \mathrm{L}(n=5)$ for males and $5.9 \pm 1.4 \mathrm{nmol} / \mathrm{L}$ for females $(n=5)$ in the adrenal gland. $K_{d}$ values very close to those found in the above tissues were also detected in the other GHS-receptor positive tissues of both sexes.

\section{Specificity of binding}

The specificity of [ $\left.{ }^{125} \mathrm{I}\right] \mathrm{Tyr}$-Ala-hexarelin binding to tissue membranes was assessed by competitive binding studies with different GHS. Table 2 shows the $\mathrm{IC}_{50}$ values of hexarelin, MK 0677 and human ghrelin calculated from the respective displacement curves in various endocrine and nonendocrine organs. Unlabeled hexarelin completely displaced radiolabeled Tyr-Ala-hexarelin from binding sites. The concentration of hexarelin required to inhibit radiotracer binding by $50 \%$ did not significantly differ among the various tissues examined and ranged from 2.7 to $5.5 \times 10^{-8} \mathrm{~mol} / \mathrm{L}$. When human ghrelin and MK 0677 were tested in the dis-
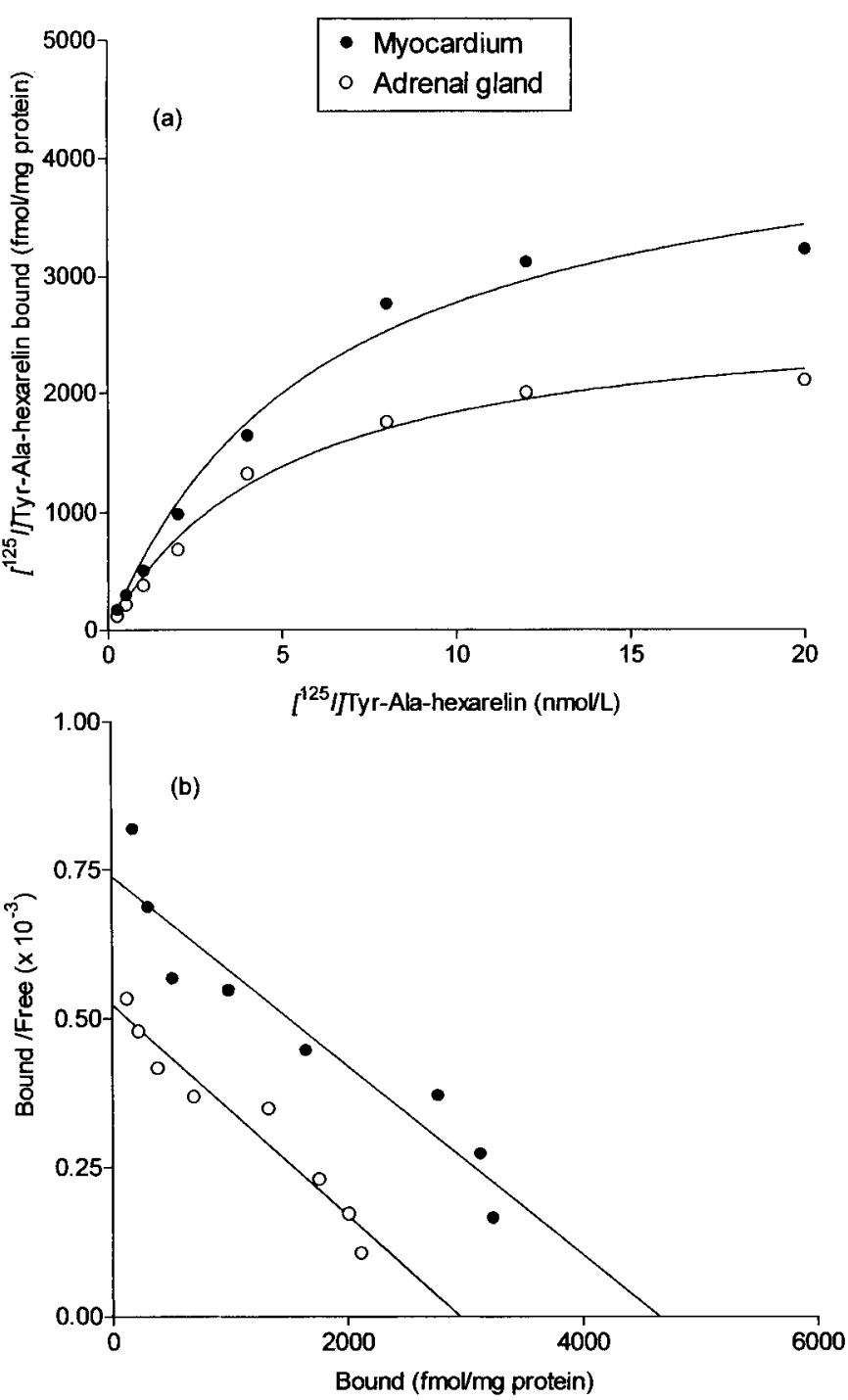

FIG. 1. Representative saturation isotherms (a) and Scatchard plots (b) of [ $\left.{ }^{125} \mathrm{I}\right] \mathrm{Tyr}-\mathrm{Ala}$-hexarelin binding to membranes from myocardium and adrenal gland of male subjects. Experiments were performed by incubating a fixed amount of membrane protein $(100 \mu \mathrm{g} /$ tube $)$ with increasing concentrations of radiolabeled Tyr-Ala-hexarelin alone (total binding) or plus $2.5 \mu \mathrm{mol} / \mathrm{L}$ unlabeled Tyr-Ala-hexarelin to define nonspecific binding. Specific binding values were obtained by subtracting nonspecific binding from total binding. The saturation curves of specific binding were analyzed by Scatchard analysis in order to calculate the maximal binding capacities and the $\mathrm{K}_{\mathrm{d}}$ values.

placement studies, a dose-dependent inhibition of binding was seen with both compounds only in the adrenal gland (Fig. 2) and in various endocrine organs such testis, ovary, pituitary and thyroid gland. In these tissues human ghrelin and MK 0677 completely displaced $\left[{ }^{125} \mathrm{I}\right] \mathrm{Ty}$ r-Ala-hexarelin with equal efficacy, but they were significantly $(P<0.05)$ less potent than hexarelin (4-5 times). By contrast, in the myocardium (Fig. 2), as well as in the other nonendocrine tissues, human ghrelin and MK 0677 (tested at concentrations of 0.1 $\mathrm{nmol} / \mathrm{L}-2 \mu \mathrm{mol} / \mathrm{L}$ ) were able to displace only $11-31 \%$ of the specifically bound radiolabeled Tyr-Ala-hexarelin. Other peptides (GHRH, SRIF) that have a known influence on GH release had no effect on the binding of $\left[{ }^{125} \mathrm{I}\right] \mathrm{Tyr}$-Ala-hexarelin 
TABLE 2. Concentrations of hexarelin, human ghrelin, and MK 0677 required to inhibit by $50 \%\left(\mathrm{IC}_{50}\right)$ the specific binding of $\left[{ }^{125} \mathrm{I}\right] \mathrm{Tyr}-\mathrm{Ala}-\mathrm{hexarelin}$ to membranes from various human tissues

\begin{tabular}{lccc}
\hline \multirow{2}{*}{ Tissue } & \multicolumn{3}{c}{$\mathrm{IC}_{50}\left(\times 10^{-8} \mathrm{~mol} / \mathrm{L}\right)$} \\
\cline { 2 - 4 } & Hexarelin & Ghrelin & MK 0677 \\
\hline Adrenal gland & $3.4 \pm 0.6$ & $17.0 \pm 2.5^{a}$ & $18.3 \pm 1.4^{a}$ \\
Testis & $2.7 \pm 1.0$ & $19.7 \pm 1.2^{a}$ & $22.0 \pm 3.2^{a}$ \\
Ovary & $3.9 \pm 1.5$ & $15.7 \pm 3.8^{a}$ & $19.3 \pm 3.2^{a}$ \\
Pituitary gland & $3.7 \pm 1.1$ & $19.3 \pm 3.3^{a}$ & $18.0 \pm 1.7^{a}$ \\
Thyroid gland & $4.6 \pm 0.8$ & $16.3 \pm 2.6^{a}$ & $17.3 \pm 2.0^{a}$ \\
Myocardium & $3.7 \pm 0.8$ & $(27 \pm 6)$ & $(16 \pm 3)$ \\
Aorta & $2.8 \pm 1.0$ & $(26 \pm 5)$ & $(20 \pm 3)$ \\
Coronary & $3.1 \pm 0.2$ & $(24 \pm 6)$ & $(18 \pm 5)$ \\
Carotid & $5.0 \pm 1.0$ & $(27 \pm 8)$ & $(20 \pm 2)$ \\
Lung & $4.8 \pm 0.8$ & $(23 \pm 9)$ & $(19 \pm 4)$ \\
Liver & $4.5 \pm 1.6$ & $(24 \pm 6)$ & $(17 \pm 7)$ \\
Skeletal muscle & $5.1 \pm 2.0$ & $(21 \pm 5)$ & $(14 \pm 4)$ \\
Kidney & $3.8 \pm 0.9$ & $(17 \pm 3)$ & $(27 \pm 4)$ \\
Adipose tissue & $3.8 \pm 1.0$ & $(19 \pm 7)$ & $(20 \pm 6)$ \\
Vena cava & $5.0 \pm 1.1$ & $(15 \pm 5)$ & $(16 \pm 5)$ \\
Uterus & $4.8 \pm 1.3$ & $(16 \pm 5)$ & $(23 \pm 5)$ \\
Skin & $5.5 \pm 1.2$ & $(11 \pm 4)$ & $(12 \pm 5)$ \\
Lymphnode & $5.3 \pm 3.3$ & $(31 \pm 8)$ & $(22 \pm 5)$ \\
\hline
\end{tabular}

The values in parentheses indicate the percentage of displacement produced by $2 \mu \mathrm{mol} / \mathrm{L}$ ghrelin or MK 0677. Values are means \pm SEM of three separate experiments.

${ }^{a} P<0.05$ vs. hexarelin.

to receptors of endocrine and nonendocrine tissues (data not shown).

\section{Discussion}

Peptidyl and nonpeptidyl GHS possess specific receptor subtypes mostly distributed at the level of the pituitary gland and the hypothalamus (6-8), where they probably mediate the classical endocrine activities of GHS, i.e. strong GHreleasing effect but also significant stimulatory effect on PRL and ACTH secretion $(4,5,28)$. On the other hand, the presence of appreciable amounts of GHS binding sites and GHSreceptor mRNA in the central nervous system may account for the central activities of GHS, such as their influence on food intake and sleep (29-32). The existence of GHS binding sites in some peripheral tissues had also been reported in animals and in humans using in vitro radioreceptor assay $(15-17,25)$ and GHS-receptor mRNA analysis (12). In particular, specific GHS binding sites had been demonstrated in the rat $(16)$ and human heart $(15,17)$ and even in human thyroid (25). Interestingly, other G-protein-coupled orphan receptors, sharing significant homology with the GHS receptors, have recently been cloned and characterized from different peripheral tissues such as thyroid, stomach, colon, pancreas and bone marrow $(10,11)$.

In the present study we have found that several endocrine and nonendocrine peripheral human tissues show specific binding values for Tyr-Ala-hexarelin which are even higher than found in the pituitary gland. This was found to be the case in the myocardium, adrenal, testis, arteries, lung, ovary, liver, skeletal muscle, and kidney. Specific binding values quite close to those detected in the pituitary were found in the thyroid gland. Lower levels of binding were observed, on the other hand, in adipose tissue, veins, uterus, skin and lymphnode, while negligible binding was found in parathy-
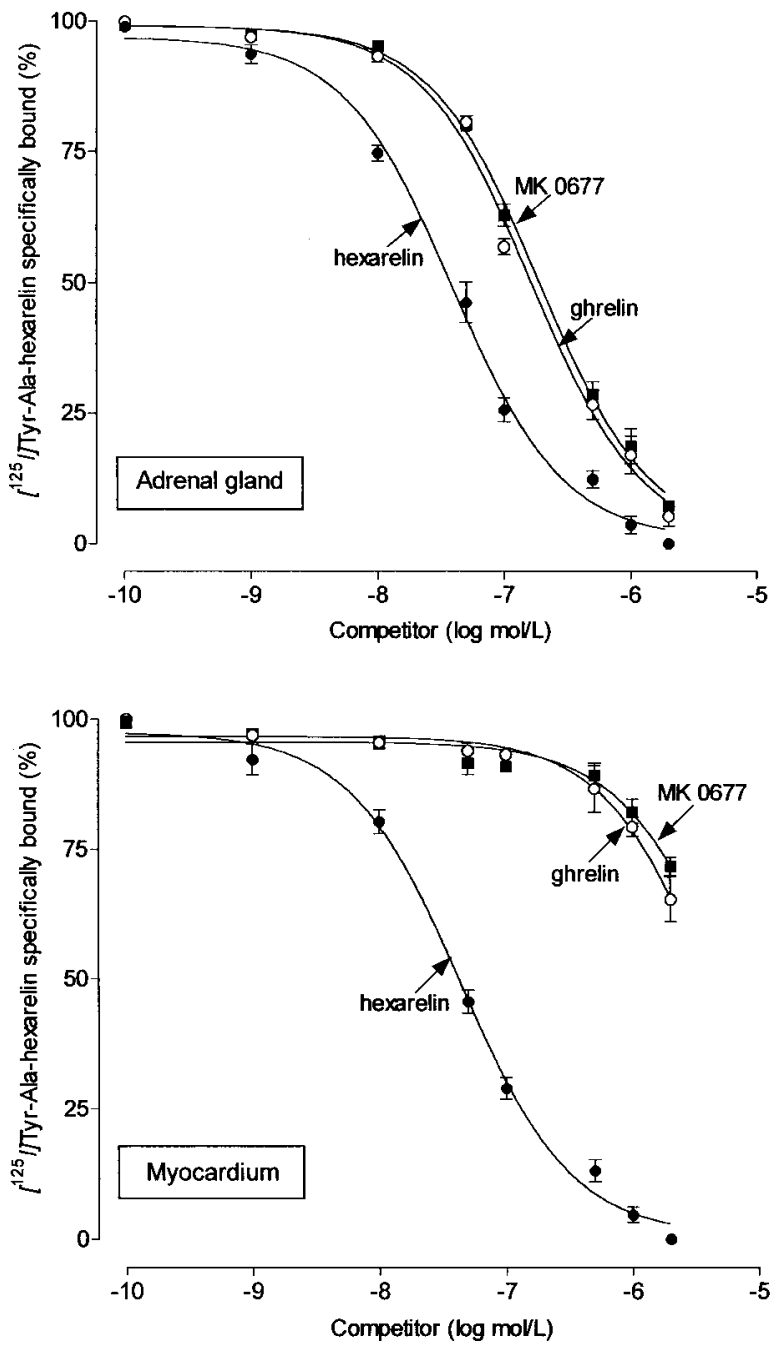

FIG. 2. Displacement of $\left[{ }^{125} \mathrm{I}\right] \mathrm{Tyr}$-Ala-hexarelin from membranes of adrenal gland and myocardium by hexarelin, human ghrelin and MK0677. Binding assays were conducted as described in Subjects and Methods. The ordinate represents binding as a percentage of control (specific binding in the absence of unlabeled competitor). Each point represents the mean \pm SEM of three separate experiments.

roid glands, pancreas, placenta, mammary gland, prostate, salivary gland, stomach, colon, and spleen. These findings indicate that GHS have widely spread receptors in some (but not all) peripheral endocrine and nonendocrine human tissues which could mediate effects other than classical endocrine and central activities (33). Evidence has been provided that treatment with peptidyl GHS exerts cardiovascular activities. In fact, coronary vasoconstriction (16) or protective effect against ischemia depending on dose and experimental conditions (18-20) and improvement of cardiac performances after myocardial infarction (23) have been observed in rats, while an increase in the left ventricular ejection fraction has been reported in humans (21). It will be noted that the myocardial effects of peptidyl GHS are elicited also in animals (18) and humans $(20,22)$ with severe GH deficiency. In addition, no cardiac effects were noted after giving nonpeptidyl GHS. One can therefore argue that the GHS binding sites in the heart are specific for peptidyl GHS only and 
mediate cardiovascular activities indepentently from their $\mathrm{GH}-$ releasing effect. This is not the case of the thyroid where both peptidyl and nonpeptidyl GHS displaced Tyr-Alahexarelin from binding sites of normal and follicular-derived neoplastic tissues and carcinoma cell lines. The thymidine incorporation and the proliferation of the latter is inhibited by both peptidyl and nonpeptidyl GHS (25). Finally, it is noteworthy that among peripheral tissues lacking GHS binding there was the stomach which has been shown as the major site of ghrelin synthesis and release (24) and the pancreas where GHS-receptor mRNA has been demonstrated (12). These data further indicate the complexity of the GHS compound/receptor interactions. Even the discovery of ghrelin as a natural GHS-like ligand (24) has not completely clarified the whole matter.

The binding of $\left[{ }^{125} I\right]$ Tyr-Ala-hexarelin to membranes from peripheral human tissues showed many of the properties typical of the ligand-receptor interaction. These included high affinity, saturability and structural specificity. The specificity of radioiodinated Tyr-Ala-hexarelin binding was very similar to that observed in other human peptidyl GHS target tissues such as the hypothalamus and the pituitary gland (6), since the binding of radioligand was displaced by unlabeled Tyr-Ala-hexarelin, hexarelin, but not by peptides (GHRH or SRIF) structurally unrelated to peptidyl GHS.

The peripheral GHS binding sites do not necessarily reflect the peripheral distribution of the classic GHS receptor cloned by Howard et al. $(4,8,9)$. At least in some tissues, they could even reflect the existence of GHS receptor subtypes different from that previously characterized in the pituitary $(6,7)$. In our study binding specificity showed remarkable differences among tissues displaying binding sites. In fact, the binding of [ $\left.{ }^{125} \mathrm{I}\right] \mathrm{Tyr}$-Ala-hexarelin was inhibited by ghrelin as well as by the nonpeptidyl spiroindoline MK 0677 in membranes from endocrine but not from nonendocrine tissues. It is worth noticing that in membranes from endocrine tissues ghrelin and MK 0677 inhibited the binding of radiolabeled Tyr-Ala-hexarelin but to a lower extent than that shown by peptidyl GHS. In all, these data clearly point toward the existence of new GHS receptor subtypes which in peripheral nonendocrine tissues seem specific for peptidyl GHS and do not bind ghrelin nor the spiroindoline MK 0677.

In conclusion, the present data demonstrate that GHS have specific receptors in a wide range of endocrine and nonendocrine human tissues and suggest that a still unknown receptor subtype, specific for peptidyl GHS, may exist in the heart and in other tissues.

\section{Acknowledgments}

We thank Profs. G. Bussolati, F. Camanni, and F. De Matteis (University of Turin) for their suggestions.

\section{References}

1. Camanni F, Ghigo E, Arvat E. 1998 Growth hormone-releasing peptides and their analogs. Front Neuroendocrinol. 19:47-72

2. Deghenghi R. 1998 Structural requirements of growth hormone secretagogues. In: Bercu BB, Walker RF, eds. Growth hormone secretagogues in clinical practice. New York: Marcel Dekker; 27-35.

3. Casanueva F, Dieguez C. 1999 Growth hormone secretagogues: physiological role and clinical utility. Trends Endocrinol Metab. 10:30-38.
4. Smith RG, Van der Ploeg LHT, Howard AD, et al. 1997 Peptidomimetic regulation of growth hormone secretion. Endocr Rev. 18:621-645.

5. Ghigo E, Arvat E, Muccioli G, Camanni F. 1997 Growth hormone-releasing peptides. Eur J Endocrinol. 136:445-460.

6. Muccioli G, Ghè C, Ghigo MC, et al. 1998 Specific receptors for synthetic GH secretagogues in the human brain and pituitary gland. J Endocrinol. 157:99-106.

7. Ong H, McNicoll N, Escher E, et al. 1998 Identification of a pituitary GHRP receptor subtype by the photoaffinity labeling approach. Endocrinology. 139:432-435.

8. Pong S-S, Chaung L-Y, Dean DC, Nargund R, Patchett AA, Smith RG. 1996 Identification of a new G-protein-linked receptor for growth hormone secretagogues. Mol Endocrinol. 10:57-61.

9. Howard HD, Feighner SD, Cully DF, et al. 1996 A receptor in pituitary and hypothalamus that functions in growth hormone release. Science. 273:974-976.

10. McKee KK, Tan CP, Palyha OC, et al. 1997 Cloning and characterization of two human G-protein-coupled receptor genes (GPR38 and GPR39) related to growth hormone secretagogue and neurotensin receptors. Genomics. 46:426-434.

11. Tan CP, McKee K, Liu Q, et al. 1998 Cloning and characterization of a human and murine T-cell orphan G-protein-coupled receptor similar to the growth hormone secretagogue and neurotensin receptors. Genomics. 52:223-229.

12. Guan XM, Yu H, Palyha OC, et al. 1997 Distribution of mRNA encoding the growth hormone secretagogue receptor in brain and peripheral tissues. Mol Brain Res. 48:23-29.

13. de Keyzer Y, Lenne F, Bertagna X. 1997 Widespread transcription of the growth hormone-releasing peptide receptor gene in neuroendocrine human tumors. Eur J Endocrinol. 137:715-718.

14. Korbonits M, Jacobs RA, Aylwin SJ, et al. 1998 Expression of the growth hormone secretagogue receptor in pituitary adenomas and other neuroendocrine tumors. J Clin Endocrinol Metab. 83:3624-3630.

15. Muccioli G, Papotti M, Ong H, et al. 1998 Presence of specific receptors for synthetic growth hormone secretagogues in the human heart. Arch Pharm (Weinheim). 358(Suppl 2):R-549.

16. Bodart V, Bouchard JF, McNicoll N, et al. 1999 Identification and characterization of a new growth hormone-releasing peptide receptor in the heart. Circ Res. 85:796-808.

17. Muccioli G, Broglio F, Valetto MR, et al. 2000 Growth hormone-releasing peptides and the cardiovascular system. Ann Endocrinol (Paris). 61:27-31.

18. De Gennaro-Colonna V, Rossoni G, Bernareggi M, Müller EE, Berti F. 1997 Cardiac ischemia and impairment of vascular endothelium function in hearts from growth hormone-deficient rats: protection by hexarelin. Eur J Pharmacol. 334:201-207.

19. Rossoni G, De Gennaro-Colonna V, Bernareggi M, et al. 1998 Protectant activity of hexarelin or growth hormone against postischemic ventricular dysfunction in hearts from aged rats. J Cardiovasc Pharmacol. 32:260-265.

20. Locatelli V, Rossoni G, Schweiger F, et al. 1999 Growth hormone-independent cardioprotective effects of hexarelin in the rat. Endocrinology. 140:4024-4031.

21. Bisi G, Podio V, Valetto RM, et al. 1999 Acute cardiovascular and hormonal effects of growth hormone (GH) and hexarelin, a synthetic GH-releasing peptide, in humans. J Endocrinol Invest. 22:266-272.

22. Bisi G, Podio V, Valetto RM, et al. 1999 Cardiac effects of hexarelin in hypopituitary adults. Eur J Pharmacol. 381:31-38.

23. Tivesten A, Bollano E, Caldahl K, et al. 2000 The growth hormone secretagogue hexarelin improves cardiac function in rats after experimental myocardial infarction. Endocrinology. 141:60-66.

24. Kojima M, Hosoda H, Data Y, Nakazato M, Matsuo H, Kangawa K. 1999 Ghrelin is a growth hormone-releasing acylated peptide from stomach. Science. 402:656-658.

25. Cassoni P, Papotti M, Catapano F, et al. 2000 Specific binding sites for synthetic growth hormone secretagogues in non-tumoral and neoplastic human thyroid tissue. J Endocrinol. 165:139-146.

26. Lowry OH, Rosebrough NL, Farr AL, Randall RJ. 1951 Protein measurement with the Folin phenol reagent. J Biol Chem. 193:265-275.

27. Scatchard G. 1949 The attraction of proteins for small molecules and ions. Ann NY Acad Sci. 51:660-672

28. Bowers CY. 1998 Growth hormone-releasing peptides. Cell Mol Life Sci. 54:1316-1329.

29. Locke W, Kirgis HD, Bowers CY, Abdoh AA. 1995 Intracerebroventricular growth hormone-releasing peptide- 6 stimulates eating without affecting plasma growth hormone. Life Sci. 55:1347-1352.

30. Torsello A, Luoni M, Schweiger F, et al. 1998 Novel hexarelin analogs stimulate feeding in the rat through a mechanism not involving growth hormone release. Eur J Pharmacol. 360:123-129.

31. Frieboes R-M, Murck K, Maier P, Schier T, Holsboer F, Steiger A. 1995 Growth hormone-releasing peptide-6 stimulates sleep, growth hormone, ACTH and cortisol in man. Neuroendocrinology. 60:76-86.

32. Copinschi G, Leproult R, Van Onderbergen A, et al. 1997 Prolonged ora treatment with MK-0677, a novel growth hormone secretagogue, improves sleep quality in man. Neuroendocrinology. 66:278-286.

33. Ghigo E, Arvat E, Broglio F, et al. 1999 Endocrine and non-endocrine activities of growth hormone secretagogues in humans. Horm Res. 51(Suppl 3):9-15. 